\title{
Knowledge, Attitude, and Implementation of Cold Chain Management in Boalemo District, Gorontalo, Indonesia
}

\author{
Paulus Pangalo1), Zulfiayu Sapiun²), Wenny Inno Ischak1), \\ Misrawatie Goi3), Hartati²) \\ ${ }^{1)}$ Study Program of Nursing, Health Polytechnics, Ministry of Health Gorontalo \\ ${ }^{2}$ Study Program of Pharmacy, Ministry of Health Gorontalo \\ 3) Study Program of Nutrition, Ministry of Health Gorontalo
}

\section{ABSTRACT}

Background: Children's health is a priority in health development with the goal of reducing child mortality. So far, high immunization coverage does not guarantee the emergence of diseases that can be prevented by immunization (PD3I). Cold Chain Management is a system used to store vaccines in good condition which refers to the vaccine supply chain for the immunization procurement chain. The purpose of this study was to examine the relationship of knowledge, attitude, and implementation of cold chain management.

Subjects and Method: This was a cross sectional study conducted at 11 health centers in Boalemo District, Gorontalo, Indonesia, in September 2018. A sample of 34 health officers was selected purposively. The dependent variable was cold chain management. The independent variables were knowledge and attitude. The data were collected by questionnaire and observation sheets. The data were analyzed by Chi square.

Cite this as:

Pangalo P, Sapiun Z, Ischak WI, Goi M, Hartati (2020).Knowledge, Attitude, and Implementation of Cold Chain Management in Boalemo District, Gorontalo, Indonesia. J Health Policy Manage. 05(02): 139-145. https://doi.org/10.26911/thejhpm.2020.05.02.06

cc (i) (-) Journal of Health Policy and Management is licensed under a Creative Commons

\section{BACKGROUND}

Health development is essentially an effort carried out by all components of the Indonesian Nation which aims to increase awareness, willingness and ability to live healthy for everyone in order to realize the highest degree of public health, as an investment for the development of socially productive human resources and economical. The success of health development is largely determined by the continuity between program and sector efforts, as well
Results: High knowledge increased positive attitude toward implementation of cold chain management $(\mathrm{OR}=5.87 ; \mathrm{p}=0.061)$. High knowledge $(\mathrm{OR}=$ 2.17; $\mathrm{p}=0.448)$ and positive attitude $(\mathrm{OR}=2.69 ; \mathrm{p}=$ 0.405 ) increased implementation of cold chain management, but they were statistically nonsignificant.

Conclusion: High knowledge and positive attitude increase implementation of cold chain management

Keywords: cold chain management, vaccine, knowledge, attitude

\section{Correspondence:}

Zulfiayu Sapiun. Department of Pharmacy, Health Polytechnics, Ministry of Health Gorontalo.Jl. Taman Pendidikan 36, Gorontalo 96123, Indonesia. Email: zulfiayu@poltekkesorontalo.ac.id. Mobile: 081244521639 as the continuity with efforts that have been carried out in the previous period.

The target of health development to be achieved in 2025 is an increase in the degree of public health, which is indicated by an increase in life expectancy, declining infant mortality rates, and maternal mortality rates, decreasing prevalence of undernutrition in children under five. The Ministry of Health has drawn up a Strategic Plan (Renstra) that refers to the National Medium-Term Development Plan (RPJMN) 2015-2019 which is part of the 2005-2025 
Long-Term Development Plan for Health (RPJPK) 2005-2025.

Considering that maternal and child health is a top priority in health development in Indonesia (Ministry of Health Republic of Indonesia, 2013), the government established Indonesian Health Ministry Regulation Number 42 year 2013 concerning about the implementation of immunization.

In 2013, the level of availability of drugs and vaccines reached $96.82 \%$, an increase from the previous year which reached $92.5 \%$. There is an improvement in the coverage of complete immunization which has increased from 41.6 percent (2007) to $59.2 \%$ (2013). Immunization coverage in Gorontalo was $80.6 \%$ (Ministry of Health Republic of Indonesia, 2013).

But in addition to paying attention to the availability and coverage of vaccines, the government must pay attention to vaccine management to be in accordance with standards to maintain vaccine quality because after all the availability and coverage have achieved good results but vaccine quality is not good, the immunization has been declared a failure. This is evidenced by the emergence of several diseases that can be prevented by immunization (PD3I).

WHO recommended to maintain vaccine quality from the time the product is made to the time of delivery, ensure the vaccine is stored and distributed in temperature $2^{\circ}-8^{\circ} \mathrm{C}$ (WHO, 2015).

Vaccine management in several countries is still experiencing sharing obstacles. Studies in India show that storing ineligible vaccines is detected in $10 \%$ of places. Although the majority of health workers have good knowledge, only $61.8 \%$ are able to apply it well (Rao et al., 2013). Studies in Malaysia show that the majority of general practitioners have a low attitude and concern for cold chain procedures (Azira 2013).
Studies in Cameroon show that despite having adequate facilities but monitoring has not been able to run well (Yakum, 2015).

Likewise, vaccine management in Indonesia. Carelessness in freezing is widely spread. The use of a vial monitor vaccine reduces this risk (Nelson et al., 2004). Studies in Purwakarta showed that the equipment and application of basic immunization vaccine cold chain by the immunization coordinator at the Purwakarta District Health Center are still not optimal in terms of quality and quantity (Gantinia et al., 2017).

A study by Kairul and Udiyono (2016) at 12 health centers in Sarolangun, Jambi Province showed the same results.

Whereas studies in Makassar showed inadequate human resources (69\%) and inadequate cold chain equipment in 25 health centers $(56 \%)$. Of the five process components assessed there are still three problems: vaccine storage is still poor in 37 health centers (82.2\%), temperature monitoring is still poor in 40 health centers (88.9\%), and recording and reporting is lacking in 31 health centers(69\%). The output component in the form of poor vaccine quality is found in four health centers (8.9\%) in Makassar(Ryza and Rismayanti, 2017).

\section{SUBJECTS AND METHOD}

\section{Study Design}

This was a cross-sectional study conducted in district vaccine management research and 11 health centers in Boalemo District, in September 2018.

\section{Populationand Sample}

The study population was all immunization managers who worked in pharmacy installations, health services, and community health centers in Boalemo District. A 
Pangalo et al./ Knowledge, Attitude, and Application of Cold Chain Management

sample of 34 health officers was selected purposively.

\section{Study Variables}

The dependent variable was implementation of cold chain management.The independent variables were knowledge and attitude.

4. Operational Definition of Variables Knowledgewas the knowledge of officers about managing cold chain management. Good knowledge was high if score $\geq 75 \%$. Attitude was a thought, tendency and feeling of the vaccine manager about vaccine (cold chain management). Attitude was stated as positive if score $\geq 75 \%$.

The application of cold chainmanagement was the compatibility between vaccine management in health services and the standards set by WHO. Health service facilities are stated to have good cold chain application $\geq 50 \%$.

\section{Study Instrument}

The questionnaire used was Azira (2013) questionnaire consisting of characteristic items, 10 knowledge items, and 11 attitude items with Cronbach's alpha 0.68-0.72.

Whereas observational use fridge inspection forms, and thermometers. Vaccine storage inspection is a type of refrigerator, refrigerator designation for vaccines, the presence of a thermometer, and temperature monitoring using a temperature card.

\section{Data Analysis}

The data in univariate analysis were described in $\mathrm{n}$ and \%. Bivariate analysis was conducted by Chi square.

\section{RESULTS}

1. Univariate analysis

Sample characteristics of this study can be seen in Table 1.

Table 1. Sample characteristics

\begin{tabular}{cccc}
\hline Characteristics & Category & n & \% \\
\hline Age (year) & $20-29$ & 9 & 26.5 \\
& $30-39$ & 15 & 44.1 \\
& $40-49$ & 8 & 23.5 \\
Gender & $50-59$ & 2 & 5.9 \\
& Male & 11 & 32.4 \\
Educational Background & Female & 23 & 67.6 \\
& Senior high school & 6 & 17.6 \\
& Diploma & 14 & 41.2 \\
& Bachelor & 13 & 38.2 \\
Knowledge field & Post Graduate & 1 & 2.9 \\
& Nurse & 11 & 32.4 \\
& Midwife & 10 & 29.4 \\
How long in charge of & Pharmacy & 4 & 11.8 \\
administering the vaccine(year) & Others & 9 & 26.5 \\
& $<5$ & 22 & 64.7 \\
& $5-10$ & 9 & 26.5 \\
Attending training & $10-20$ & 2 & 5.9 \\
& $>20$ & 1 & 2.9 \\
Use of Guidelines & Yes & 13 & 38.2 \\
& No & 21 & 61.8 \\
Concerned about Cold Chain & Yes & 26 & 76.5 \\
Management Efforts & No & 8 & 23.5 \\
& Yes & 31 & 91.2 \\
& No & 3 & 8.8 \\
\hline
\end{tabular}


Pangalo et al./Knowledge, Attitude, and Cold Chain Management

\section{Bivariate analysis}

Table 2. Relationships between knowledge and attitude

\begin{tabular}{lcccc}
\hline \multirow{2}{*}{ Knowledge } & \multicolumn{2}{c}{ Attitude } & \multirow{2}{*}{ OR } & \multirow{2}{*}{ p } \\
\cline { 2 - 3 } & Positive (\%) & Negative (\%) & & 0.061 \\
High & $22(88.0 \%)$ & $3(12.0 \%)$ & & 5.87 \\
Low & $5(55.6 \%)$ & $4(44.4 \%)$ & & \\
\hline
\end{tabular}

Table 2 showed the relationships between attitude $(\mathrm{OR}=5.87 ; \mathrm{p}=0.061)$, and it was knowledge and attitude. Table 2 showed marginally significant.

that high knowledge increased positive

Table 3. Relationships between knowledge, attitude, and cold chain management

\begin{tabular}{lcccc}
\hline \multicolumn{1}{c}{ Independent } & \multicolumn{2}{c}{ Cold chain management } & \multirow{2}{*}{ OR } & p \\
\cline { 2 - 3 } Knowledge & Good (\%) & Poor (\%) & & \multirow{2}{*}{0.448} \\
High & $13(52.0 \%)$ & $12(48.0 \%)$ & & \\
Low & $3(33.3 \%)$ & $6(66.7 \%)$ & & \\
Attitude & & & & \multirow{2}{*}{0.405} \\
Postive & $14(51.9 \%)$ & $13(71.4 \%)$ & & \\
Negative & $2(28.6 \%)$ & $5(48.1 \%)$ & & \\
\hline
\end{tabular}

Table 3 showed the relationships between knowledge, attitude, and cold chain management. Table 2 showed that high knowledge $(\mathrm{OR}=2.17 ; \mathrm{p}=0.448)$ and positive attitude $(\mathrm{OR}=2.69 ; \mathrm{p}=0.405)$ increased cold chain management, but they were statistically non-significant.

\section{DISCUSSION}

\section{Characteristics of Cold Chain Management Officers}

Based on data that from 34 health officers, the majority of them were aged between 30 to 39 years $(44.1 \%)$. It means that the majority of them are in the most productive period of work.

The majority of health officers are women (67.6\%). Individual sex affects individual productivity. As many as $41.2 \%$ of health officers had diploma education and worked as nurse (32.4\%). There is a positive and significant influence of educational variables on employee work productivity (Putri, 2016).
Education is important in influencing individual mind. Perry and Potter (2005) argue that education levels can increase knowledge about health. An educated person when encountering a problem will try to think of the best possible way to solve the problem. Through an educational process that involves a series of activities, an individual will gain better knowledge, understanding, expertise and insight. Tenure also affects productivity. Most of health officers worked as immunization officers for $<5$ years $(64.7 \%)$.

As many as $61.8 \%$ health officers have not trained toward cold chain management. They follow the cold chain management guidelines.

\section{Knowledge toward Cold Chain Management}

Knowledge is a result of curiosity through sensory processes, especially in the eyes and ears of certain objects. Knowledge is an important domain in the formation of open behavior (Donsu, 2017). 
As many as $94.1 \%$ of health officers know that the optimal temperature for vaccines is $2-8^{\circ} \mathrm{C}$. Most of health officers know that vaccines will break if frozen. They know that food and drink cannot be put together with vaccines. Vaccines cannot be put on the fridge door, transferring vaccine is needed if electricity is more than 72 hours. The vaccine will be damaged if exposed to heat, the response also agreed that the vaccine refrigerator cannot be placed near a source of heat (near sunlight, microwave, stove). But only $41.2 \%$ know that a thermometer must be placed at the bottom of the refrigerator. $76.5 \%$ knew that recording the temperature on a temperature card was needed. of all these items, an average knowledge of $80.6 \%$ was obtained or at a good level.

Vaccine managers who were participated in this study, $73.5 \%$ had high knowledge. This results are lower than a study conducted in Kelantan, Malaysia, which is 78.7\% (Azira et al., 2013). Another study in Turkey reported that $96.3 \%$ midwives had high knowledge (Efe and Oncel, 2008).

\section{Attitude toward cold chain management}

$79.4 \%$ of health officers have a positive attitude towards implementation of cold chain management. A study in China reported that health officers believe that vaccine management is important (96.7\%) (Zhang et al., 1999). However this is not in line with research in Kelantan, Malaysia which found that managers' attitudes were not good. Most respondents have a negative attitude towards cold chain management and only $20 \%$ think that cold chain management is important (Azira et al., 2013). Based on observation from this study, only $50 \%$ of health service facilities were categorized as good. Ice lined Vaccine Refrigenerator or freezer used by health center was TCW 3000 and TCWSDD (Dometic, 2014).

\section{Implementation of cold chain management}

Icelined Vaccine Refrigenerator type TCW SDD is a refrigenerator using solar power so that it can reduce the risk of temperature drop when the power goes out. The author find that maintenance is still lacking so that it can affect the effectiveness of the tool. Vaccine delivery practices in Boalemo District are in line with studies in Cameroon showing that although they have adequate facilities, monitoring has not been able to run well (Yakum, 2015).

A study in Purwakarta showed that the equipment and implementation of the basic immunization vaccine cold chain by the immunization coordinator at the Purwakarta District Health Center were still not optimal in terms of quality and quantity (Gantinia et al., 2017). A study byKairul and Udiyono (2016) at 12 health centers in Sarolangun Regency, Jambi, showed the same results.

A study in Makasssar showed inadequate human resources (69\%) and inadequate cold chain equipment in 25 community health centers (56\%). Fromassessment, the author found that 37 health centershad poor vaccine storage (82.2\%) and 40 health centers had poor temperature monitoring.

\section{Relationship between knowledge and cold chain management}

The results of this study showed that high knowledge increased cold chain management, but it was statistically non-significant. The results of this study was in line with a study conducted in Malaysia. It reported that although health workers have high knowledge toward cod chain management, they do not implement it well (Azira et al., 2013).

\section{Relationship between attitude with cold chain management}

The results of this study showed that positive attitude increased cold chain manage- 
ment, but it was statistically non-significant. Although the officer has a good attitude towards cold chain management but in its implementation it has no influence.

Different result was reported by Azira et al. (2013) in Malaysia. Their study showed that positive attitude improved implementation of cold chain management. This different result may be caused by the lack of supervision.

\section{Relationship between knowledge and attitude towards cold chain management}

The results of this study showed that high knowledge increased positive attitude, and it was marginally significant. The results of this study was in line with a study by Purnamasari (2010), which reported that there was a direct effect between knowledge on attitudetowards cold chain management in health workers.

Positive attitudein health workers is supported by knowledge, education level, and tenure, so that their experience and skills add to their own insights and encourage themselves to behave better in their management (Wawan and Dewi, 2012).

The other study also reported that high knowledge improved positive attitude 5.87 times $(\mathrm{OR}=5.87)$ (Pracoyo et al., 2013; Nurzia, 2018).

Based on the results of this study, it can concluded that implementation of cold chain management increased with high knowledge and positive attitude.

\section{AUTHOR CONTRIBUTION}

Paulus Pangalo conducted the data collection and wrote the manuscript. Zulfiayu Sapiun, Misrawatie Goi, and Hartati collected the data. Wenny Ino Ischak run the data analysis and interpreted the results.

\section{CONFLICT OF INTEREST}

There is no conflict of interest.
FUNDING AND SPONSORSHIP

This research was funded by the Indonesian Ministry of Health.

\section{ACKNOWLEDGEIMENT}

We would like to thank the Director of Health Polytechnics Ministry of Health Gorontalo and health centers in Boalemo District, Gorontalo.

\section{REFERENCE}

Azira B, Norhayati MN, Norwati D (2013). Knowledge, attitude and adherence to cold chain among general practitioners in Kelantan, Malaysia.Int J Collab Res Intern Med Public Health, 5(3): 157-167.

Dometic (2014). B Medical systems i cold chain b medical systems your global partner to save lives.

Donsu (2017). Psikologi keperawatan, aspek-aspek psikologi, konsep dasar psikologi, teori perilaku manusia (Nursing psychology, aspects of psychology, basic concepts of psychology, theories of human behavior). Yogyakarta: Pustaka Baru Press.

Efe, Oncel O (2008). What do midwives in one region in Turkey know about. Midwifery, 24: 328-334. doi: 10.1016/j.midw.2006.11.002.

Gantinia AU, Sadeli M, Saleh T (2017). Gambaran penerapan rantai dingin vaksin imunisasi dasar di Purwakarta tahun 2017 (An overview of the application of the basic immunization vaccine cold chain in Purwakarta in 2017').

Kairul A, Udiyono LDS (2016). Gambaran pengelolaan rantai dingin vaksin program imunisasi dasar (Studi di 12 Puskesmas Induk Kabupaten Sarolangun). Jurnal kesehatan masyarakat, 4(6): 417-423. https://media.neliti.com/media/publicaTIONS/1632- 
53-ID-gambaran-pengelolaan-rantaidingin-vaksi.pdf.

Ministry of Health (2013). Basic Health Research. Jakarta.

Nelson CM, Wibisono $\mathrm{H}$, Purwanto $\mathrm{H}$, Mansyur I, Moniaga V, Widjaya A (2004). Hepatitis B vaccine freezing in the Indonesian cold chain: Evidence and solutions. Bulletin of the World Health Organization, 82(2): 99-105. doi: 10.1590/Soo42-96862004000200006.

Nurzia N (2018). Hubungan pengetahuan dan sikap bidan di RSUD H. Abdul Manap Kota Jambi tentang penyimpanan vaksin tahun 2018 (The relationship of knowledge and attitudes of midwives at the Abdul Manap Hospital in Jambi City about 2018 vaccine storage).

Pracoyo NE, Jekti RP, Puspandari N (2013). Hubungan antara pengetahuan dan sikap pengelola vaksin dengan skor pengelolaan vaksin di daerah kasus difteri di Jawa Timur (The relationship between knowledge and attitudes of vaccine administrators with vaccine management scores in diphtheria case areas in East Java). Media Litbangkes, 23(3): 102-109.

Purnamasari (2010). Faktor-faktor yang berhubungan dengan sikap petugas PBF terhadap pengelolaan Cold Chain (Factors related to the attitude of pbf officers towards cold chain management). http://lib.ui.ac.id/file?file $=$ digital/20307528-T31361-Faktor-faktor-full text.pdf.

Putri RH (2016). Pengaruh pendidikan, pengalaman kerja dan jenis kelamin terhadap produktivitas kerja (Effects of education, work experience and gender on work productivity). Univer- sitas Negeri Yogyakarta.

Rao S, Naftar S, Baliga S (2013). Evaluation, awareness, practice and management of cold chain at the primary health care centers in coastal South India. J Chem Inf Model, 53(9): 1689-1699. doi: 10.1017/CBO9781107415324.004 .

Ryza JBN, Rismayanti DSA (2017).Imunisasi dasar di kota Makassar implementation of vaccine cold chain procedures on basic immunization services in Makassar. 25: 88. https://core.ac.uk/download/pdf/77621591.pdf.

Sudiharti S (2012).Hubungan pengetahuan dan sikap dengan perilaku perawat dalam pembuangan sampah medis di rumah sakit PKU Muhammadiyah Yogyakarta (Relationship of knowledge and attitude with nurses' behavior in medical waste disposal in PKU Muhammadiyah Yogyakarta hospital), Jurnal Kesehatan Masyarakat. 6(1): 49-59.

Wawan, Dewi (2012). Pengukuran dalam bidang pendidikan (Measurement in education). Jakarta: Grasindo.

WHO (2015). The vaccine cold chain, in Immunisation in practice. WHO, 46. www.who.int/immunization/docume nts/IIP2015_Module2.pdf.

YakumMN, Ateudjieu J, Walter EA, Watcho $P$ (2015). Vaccine storage and cold chain monitoring in the North West region of Cameroon: a cross sectional study. BMC Res Notes, 8(145): 1-7. doi: 10.1186/s13104-015-1109-9

Zhang X, Wang L, Zhu X, Wang K. (1999). Knowledge, attitude and practice survey on immunization service delivery in Guangxi and Gansu, China. Soc Sci Med. 49: 1125-1127. 